\title{
PEMBARUAN PENDIDIKAN ISLAM DI MAKASSAR; STUDI KASUS PESANTREN MODERN PENDIDIKAN AL QUR'AN IMMIM TAMALANREA MAKASSAR (Sebuah Critical Review atas Disertasi Karya Muljono Damopolii)
}

\author{
Cahaya Khaeron \\ Universitas Muhammadiyah Metro \\ C.Khaeroni@gmail.com
}

\begin{abstract}
Abstrak
The existence of a scientific work is the main thing that must be owned by the higher education world. In this case, the existence of a college will be determined by how high the productivity of scientific works produced by academics in it. The high scientific work is of course must be followed with the quality of the resulting quality. One way to measure the quality of a scientific work is through a critical review. The important role of critical review of scientific work is not just a report or writing about the contents of a scientific article alone, but rather to evaluation, such as reviewing or reviewing, interpreting and re-analyzing a scientific work. This paper attempts to provide a critical review model for a scientific work, in which case a dissertation by Muljono Damopolii is chosen. The method used in this study is a critical-analysis method, with systematization of the following steps; Briefly describe Muljono Damopolii's thoughts and views on his dissertation; Conducting critical analysis both in terms of theory and methodological aspects of the ideas that have been produced Muljono Damopolii in his dissertation related to the issue of renewal of Islamic education in the Modern School of Education Al Quran IMMIM Tamalanrea Makassar; Providing a new offer in terms of both theory and methodological to the dissertation of Muljono Damopolii's work.
\end{abstract}

Keyword: Critical Review, Dissertation of Islamic Education

\begin{abstract}
Abstrak
Keberadaan sebuah karya ilmiah merupakan hal utama yang harus dimiliki dunia pendidikan tinggi. Dalam hal ini, eksistensi sebuah perguruan tinggi akan sangat ditentukan dari seberapa tingginya produktifitas karyakarya ilmiah yang dihasilkan para akademisi di dalamnya. Tingginya karya ilmiah ini tentu saja harus dibarengi pula dengan mutu kualitas yang dihasilkan. Adapun salah satu cara untuk mengukur kualitas sebuah karya ilmiah adalah melalui critical review. Peran penting critical review terhadap karya ilmiah bukan hanya merupakan laporan atau tulisan tentang isi suatu artikel ilmiah semata, tetapi lebih kepada evaluasi, seperti mengulas atau mereview, menginterpretasi serta menganalisis ulang terhadap suatu karya ilmiah. Tulisan ini mencoba memberikan model critical review terhadap sebuah karya ilmiah, yang dalam hal ini dipilih disertasi karya Muljono Damopolii. Metode yang digunakan dalam penelitian ini adalah metode analisis-kritis, dengan sistematisasi langkah-langkah sebagai berikut;
\end{abstract}


Menguraikan secara singkat mengenai hasil pemikiran dan pandangan Muljono Damopolii atas disertasi yang ditulisnya; Melakukan analisis kritis baik dari segi teori maupun segi metodologis terhadap gagasan yang telah dihasilkan Muljono Damopolii dalam disertasinya berkaitan dengan persoalan pembaruan pendidikan Islam di pesantren Modern Pendidikan Al qur'an IMMIM Tamalanrea Makassar; Memberikan tawaran baru baik dari segi teori maupun metodologis terhadap disertasi karya Muljono Damopolii.

Keyword: Critical Review, Disertasi Pendidikan Islam

\section{A. PENDAHULUAN}

Keberadaan sebuah karya ilmiah merupakan syarat mutlak yang harus dimiliki dunia pendidikan tinggi. Hal ini disebabkan, selain dari tercapainya proses pembelajaran dan sarana-prasarana yang memadai, maju mundurnya eksistensi sebuah perguruan tinggi akan sangat ditentukan dari seberapa tingginya produktifitas karya-karya ilmiah yang dihasilkan para akademisi di dalamnya. Tingginya karya ilmiah ini tentu saja harus dibarengi pula dengan mutu kualitas yang dihasilkan dari karya ilmiah itu sendiri sehingga dapat menjadi motor penggerak kemajuan peradaban sebuah perguruan tinggi.

Beberapa waktu terakhir ini dunia perguruan tinggi di Indonesia sempat dihebohkan dengan adanya tindak plagiarisme di salah satu perguruan tinggi Negeri ternama di Jakarta. Bahkan tidak tanggung-tanggung tindakan plagiat tersebut justru dilakukan pada tingkatan doktoral, sebuah level pendidikan dimana hasil karya ilmiahnya diharapkan dapat memberikan kontribusi baru dan signifikan dalam pengembangan kualitas keilmuan, ${ }^{1}$ namun yang terjadi justru

1 Lihat: https://tirto.id/temuan-plagiatdisertasi-di-universitas-negeri-jakarta-cvrZ, lihat juga:

https://www.cnnindonesia.com/nasional/20170926 173228-20-244190/plagiarisme-tinggi- sebaliknya. Hal ini tentu saja menyisakan pertanyaan besar bagi setiap para akademisi di Indonesia, benarkah kualitas karya ilmiah pendidikan kita sebegitu buruknya? Dengan tidak bermaksud untuk menggeneralisir, muncul pula sebuah pertanyaan, mungkinkah fenomena terjadinya plagiarisme diperguruan tinggi ini merupakan sebuah fenomena gunung es yang tidak hanya terjadi di salah satu perguruan tinggi saja, tetapi banyak terjadi dimana-mana?

Tulisan ini pada dasarnya tidak bermaksud untuk meneliti dan menjawab mengenai fenomena plagiarisme tersebut, akan tetapi lebih diarahkan pada bagaimana langkah dan proses yang harus ditempuh dalam menganalisis sebuah karya ilmiah, yang biasanya sering disebut dengan istilah critical review. Critical Review secara singkat dapat diartikan sebagai sebuah evaluasi terhadap suatu hasil penelitian baik berupa buku, skripsi, tesis, disertasi maupun artikel. Critical Review juga bukan hanya merupakan laporan atau tulisan tentang isi suatu buku atau artikel, tetapi lebih kepada evaluasi, seperti mengulas atau mereview, menginterpretasi serta menganalisis. Selain itu, critical review bukanlah

Menristekdikti-berhentikan-rektor-unj/. Lihat juga: https://news.okezone.com/read/2017/08/28/65/176 4584/ya-ampun-disertasi-yang-diduga-plagiat-takditemukan-di-perpustakaan-kampus-unj 
merupakan pembuktian benar atau salahnya suatu artikel atau buku. Tetapi lebih berbicara mengenai keunggulan dan kelemahan sebuah karya yang kemudian dijadikan pertimbangan seorang reviewer. Keberadaan critical review terhadap sebuah karya ilmiah akan sangat membantu setiap akademisi untuk tidak hanya pasrah menerima sebuah karya ilmiah sebagai sesuatu yang final dan mutlak kebenarannya, tetapi lebih pada upaya agar setiap akademisi dapat terus selalu bersikap skeptis, kritis, serta mau menggali lebih jauh sebuah karya ilmiah demi kemajuan ilmu dan peradaban.

Tulisan ini mencoba memberikan model critical review terhadap sebuah karya ilmiah, yang dalam hal ini dipilih disertasi karya Muljono Damopolii. dengan harapan dapat menambah wawasan khazanah keilmuan dan keislaman ditanah air tercinta.

\section{B. METODE PENELITIAN}

Metode yang digunakan dalam penelitian ini adalah metode analisis kritis, dengan sistematisasi langkah-langkah sebagai berikut;

1. Menguraikan secara singkat mengenai hasil pemikiran dan pandangan Muljono Damopolii atas disertasi yang ditulisnya.

2. Melakukan analisis atau evaluasi kritis baik dari segi teori maupun segi metodologis terhadap gagasan yang telah dihasilkan Muljono Damopolii dalam disertasinya berkaitan dengan persoalan pembaruan pendidikan Islam di pesantren Modern Pendidikan Al qur'an IMMIM Tamalanrea Makassar.

3. Memberikan tawaran baru baik dari segi teori maupun metodologi terhadap disertasi karya Muljono Damopolii.

\section{PEMBAHASAN}

Pada bagian hasil dan pembahasan berikut ini penulis bagi ke dalam dua poin pokok. Bagian pertama berisi tentang pemaparan poin-poin utama yang dibahas dalam disertasi Muljono Damopolii pada setiap bab. Sementara pada bagian kedua akan lebih ditekankan pada poin kritik dari penulis terhadap hasil disertasi Muljono Damopolii, baru kemudian dilanjutkan pada kritik dan tawaran-tawaran metodologis yang penulis usulkan terhadap karya disertasi Muljono Damopolii.

Judul disertasi:

Pembaruan Pendidikan Islam di Makassar; Studi Kasus Pesantren Modern Pendidikan Al Qur'an IMMIM Tamalanrea Makassar.

Penulis : Muljono Damopolii

Terbitan : SPS UIN Jakarta

Konsentrasi : Pendidikan Islam

Tahun : 2006

\section{Latar Belakang Masalah}

Disertasi ini bertitik tolak dari sebuah pernyataan kritis Azyumardi Azra yang mengatakan bahwa tidak akan ada banyak lembaga-lembaga pendidikan Islam tradisional seperti pesantren yang mampu bertahan menghadapi ekspansi dari sistem pendidikan umum/sekuler. Dan pada akhirnya hanya akan berlanjut dengan tiga konsekuensi; Pertama, Pesantren lenyap tergusur oleh sistem pendidikan umum; kedua, pesantren mengalami transformasi menjadi lembaga pendidikan umum; ketiga, pesantren akan menyesuaikan diri dan mengadopsi sedikit banyak isi dan metodologi pendidikan umum. Seolah mengamini pernyataan tersebut, Muljono Damopolii melalui penelitian disertasinya ingin mencoba membuktikan bagaimana arah 
perkembangan

lembaga-lembaga

pendidikan Islam dalam menghadapi

ekspansi sistem pendidikan umum (sistem pendidikan umum dalam hal ini dapat pula diartikan sebagai modernitas) yang dalam hal ini dia fokuskan penelitiannya di Pesantren Modern Pendidikan Al Qur'an IMMIM Tamalanrea Makassar. Secara garis besar tema penelitian yang dia tawarkan dalam penelitian disertasinya tersebut adalah wacana pembaruan pendidikan Islam.

Muljono Damopolii menyoroti bahwa lembaga-lembaga pendidikan Islam seperti pesantren dalam konteks kekinian, tidak bisa lagi hanya bertahan dan berkutat pada persoalan dan karakteristik tradisionalnya semata, melainkan harus mentransformasikan dirinya sesuai dengan tuntutan kebutuhan masyarakat dan kondisi daerah yang bersangkutan, lembaga pendidikan Islam yang cenderung terlalu mempertahankan sifat ketradisionalan an sich, akan sangat sulit untuk dapat survive. Hanya saja yang sangat disayangkan oleh Muljono Damopolii adalah mengenai minimnya kajian-kajian penelitian yang khusus menelaah pembaruan pendidikan Islam di Makassar, sampai-sampai dia sendiri menegaskan bahwa penelitian di ranah tersebut cenderung masih sangatlah minim sekali.

\section{Rumusan Masalah}

Rumusan masalah yang dikaji dalam disertasi Muljono Damopolii adalah "Bagaimana corak pembaruan pendidikan Islam di Makassar yang direpresentasikan oleh Pesantren Modern Pendidikan Al Qur'an Tamalanrea Makassar?"

\section{Pentingnya topik penelitian}

Penelitian Muljono Damopolii penting untuk memberikan penjelasan secara lebih terperinci mengenai bagaimana corak-corak pembaruan pendidikan Islam di Makassar. Penelitian yang dilakukan Muljono Damopolii ini memberikan wawasan berharga bagi para sarjana pendidikan Islam, khususnya untuk melihat bagaimana corak-corak dan karakteristik pembaruan pendidikan Islam.

\section{Hasil penelitian terdahulu}

Muljono Damopolii telah menelaah karya-karya para peneliti sebelumnya, diantaranya seperti karya:

a. Zamakhsyari Dhofier, yang meneliti tentang ciri paternalistik yang terdapat dalam kehidupan dunia pesantren. Di sini, ia mengkaji bagaimana pandangan hidup kiai sebagai pemimpin pondok pesantren. Selanjutnya, M. Dawam Raharjo memuat kumpulan tulisan mengenai pondok pesantren dan melakukan kajian terhadap peranan kiai serta fungsi pesantren dalam memotivasi masyarakat untuk beralih dari kehidupan tradisional ke kehidupan modern yang semakin sulit dihindari.

b. Pada tahun 1994, penelitian Mastuhu yang diterbitkan oleh IndonesianNetherlands Coorperation in Islamic Studies (INIS) dengan judul: Dinamika Sistem Pendidikan Pesantren: Studi Kajian tentang Unsur dan Nilai Sistem Pendidikan Pesantren. Penelitian yang menggunakan pendekatan sosiologisantropologis dan fenomenologisinteraksi simbol ini mengambil enam pondok pesantren sebagai obyek penelitiannya. Secara komprehensif, penelitian ini telah mengetengahkan bagaimana dinamika sistem pendidikan pesantren berupa gerak perjuangan pesantren di dalam memantapkan identitas dan 
kehadirannya di tengah-tengah kehidupan bangsa yang sedang membangun. Dengan begitu, sistem pendidikan pesantren menjadi mantap eksistensinya sebagai subsistem pendidikan nasional. Akan tetapi, penelitian Mastuhu ini secara spesifik tidak membicarakan pembaruan pendidikan pesantren.

c. Manfred Ziemek telah melakukan penelitian dengan menitikberatkan kajiannya terhadap peranan kiai dan pondok pesantren dalam perubahan sosial. Sedangkan Hiroko Horikoshi, dalam penelitiannya, memfokuskan kajiannya kepada bagaimana peranan kiai sebagai perantara kebudayaan (cultural broker) melalui studi kasus pada Pondok Pesantren Cipari di Garut, Jawa Barat.

d. Di Sulawesi Selatan, seorang peneliti dari Balai Penelitian Lektur Keagamaan Ujungpandang, Abd. Azis Al Bone, telah melakukan editing terhadap lima hasil penelitian tentang pesantren di Sulawesi Selatan. Hasil editing itu diberi judul "Transformasi Kelekturan Pesantren di Sulawesi Selatan". Dalam buku ini diangkat sisi tertentu yang selama ini sering luput dari pengamatan para pemerhati masalah pesantren, yaitu transformasi kelekturan pesantren. Akan tetapi, penelitian ini tidak membahas transformasi yang berlangsung pada seluruh subsistem pesantren. Dengan demikian, penelitian tersebut tentu saja jauh dari pembahasan sekitar dinamika elemen-elemen pokok yang dimiliki oleh lembaga pesantren.

e. Bahaking Rama juga melakukan studi tentang pesantren yang diberi judul "Pembaharuan Pendidikan Pesantren
As'adiyah Sengkang-Wajo Sulawesi Selatan". Dalam penelitian itu, Rama mengungkapkan aspek-aspek pembaruan pendidikan yang terjadi di Pesantren As'adiyah. Di sini, obyek penelitiannya jelas, yaitu lembaga pesantren yang nama legalnya adalah "Pesantren As'adiyah Sengkang" dan lokasinya terletak di tengah-tengah komunitas kaum muslimin yang nuansa keagamaannya sangat kental.

\section{Metodologi penelitian}

Metodologi penelitian yang digunakan oleh Muljono Damopolii adalah metode penelitian kualitatif, dengan tetap mengakomodasi dimensi kuantitatif. Selanjutnya, Muljono menggunakan model penelitian grounded research atau grounded theory yang intinya adalah semua analisis harus berdasarkan data yang ada dan bukan berdasarkan berbagai ide yang ditetapkan sebelumnya. Peneliti tidak memulai penelitiannya dengan satu teori tertentu lalu membuktikannya, tetapi memulai dengan suatu bidang kajian dan hal-hal yang terkait dengan bidang tersebut. Dari sisi pendekatan studi, penelitian Muljono ini menggunakan pendekatan sosiologis dan historis. Adapun metode pengumpulan data yang digunakan dalam penelitian Muljono ini ada empat metode, yaitu: observasi, wawancara, dokumentasi, dan penelusuran referensi.

\section{Logika dan Sistematika Penulisan}

Disertasi Muljono Damopolii ini disusun dalam enam bab: Pertama, berisi pendahuluan meliputi latar belakang masalah, identifikasi masalah, pembatasan masalah, perumusan masalah, tujuan penelitian, kegunaan penelitian dan sistematika penulisan. Kedua, mengemukakan landasan teori dan 
kerangka berpikir. Ketiga, mengemukakan metodologi penelitian, meliputi tempat penelitian dan alasan pemilihan, waktu penelitian, metode penelitian, data dan sumber data, prosedur pengumpulan data, Analisis data penelitian, pengecekan keabsahan data, dan tahap-tahap penelitian. Keempat, mengemukakan datadata hasil penelitian meliputi kondisi objektif lokasi penelitian termasuk sejarah pembaruan pendidikan Islam di Pesantren Modern Pendidikan Al-Qur'an IMMIM Tamalanrea Makassar. Kelima, menguraikan mengenai analisis hasil penelitian yaitu rekapitulasi hasil temuan penelitian dan pembahasan hasil temuan penelitian. Terakhir, berisi penutup, yang terdiri dari kesimpulan dan saran.

\section{Faktor-faktor Pendorong Pembaruan Pendidikan Pesantren}

Ada beberapa faktor pendorong pembaruan pendidikan pesantren diantaranya yaitu: a) faktor politik; faktor ini didasari oleh alasan mendasar bahwa karena masih adanya pengaruh perpecahan yang ditimbulkan oleh rongrongan PKI pasca tahun 1975, maka pendirian pesantren ini ditujukan untuk dapat mempersatukan santri yang berasal dari berbagai latar belakang yang berbeda, b) faktor kondisi obyektif pendidikan Islam, hal ini didasari satu alasan bahwa di Makassar masih terkesan kuat akan kondisi pendidikan Islam yang masih tidak kondusif untuk melahirkan kader-kader umat Islam yang mampu berkompetisi di masa depan, 3) Faktor sosiologiskeagamaan masyarakat muslim Makassar, hal ini didasari oleh alasan bahwa memang sudah sepantasnya masyarakat Makassar yang mayoritas muslim dan dikenal kuat memegang teguh agamanya, memiliki sebuah pesantren yang modern dan unggul, sehingga diharapkan dapat membina dan meningkatkan kualitas umat Islam itu sendiri. 4) faktor pengetahuan agama jamaah masjid yang relatif masih rendah, kendatipun masyarakat muslim adalah mayoritas, namun pada kenyataannya pengetahuan agamanya masih relatif rendah, oleh sebab itulah pendirian pesantren ini diasumsikan dapat mempercepat peningkatannya.

\section{Usaha-usaha Pembaruan \\ Komponen Pendidikan Pesantren}

Usaha-usaha pembaruan pesantren IMMIM ditujukan pada beberapa komponen diantaranya adalah: komponen tujuan pendidikan, komponen kelembagaan dan keorganisasian (meliputi: bidang kesekolahan, bidang kepesantrenan, dan bidang kekampusan), komponen kurikulum (50:50\% pengetahuan umum dan agama dibuat seimbang, bahasa diutamakan adalah bahasa Arab, inggris, dan Indonesia), komponen metodologi pembelajaran (dikembangkannya system metode halaqah, klasikal, quantum learning, metode taraduf, istinjaiyah, istiqraiyah, al-bahsi/observasi, ceramah, tarjamah), dan komponen tenaga pengajar.

\section{Fungsi dan Implikasi Pembaruan Pendidikan Pesantren IMMIM terhadap Masyarakat}

Pembaruan pesantren IMMIM telah membawa dampak yang begitu luas bahkan semakin memantapkan institusinya dalam mengimplementasikan fungsifungsinya dimasyarakat, diantaranya: fungsi sebagai lembaga pendidikan, fungsi sebagai lembaga sosial, fungsi sebagai lembaga penyiaran agama, fungsi sebagai reproduksi ulama, dan fungsi sebagai pelestari tradisi Islam. Sedangkan 
implikasinya bagi masyarakat meliputi: implikasi ekonomi dan implikasi sosial.

\section{Corak Pembaruan Pendidikan Pesantren Modern Pendidikan Al Qur'an IMMIM Makassar}

Secara garis besar corak pembaruan pendidikan pesantren modern pendidikan Al Qur'an IMMIM Makassar yang sekaligus juga merupakan temuan-temuan dari hasil penelitian Muljono Damopolii diantaranya dapat diklasifikasikan sebagaimana berikut: 1) ditinjau dari sisi komponen tujuan pendidikan, maka pembaruan lembaga pendidikan Islam di Makassar bercorak dinamis; 2) ditinjau dari komponen kelembagaan dan keorganisasian maka pembaruan pendidikan Islamnya bercorak Transformatif; 3) ditinjau dari komponen kurikulum cenderung bercorak fleksibel; 4) ditinjau dari komponen metodologi pembelajaran cenderung bercorak eklektifinovatif; 5) ditinjau dari sisi komponen tenaga pengajar cenderung bercorak professional.

\section{CRITICAL REVIEW}

\section{Kritik Poin Pendahuluan}

Dalam setiap kegiatan penelitian, ${ }^{2}$ membuat sebuah konstruksi ${ }^{3}$ yang baik

2 Penelitian dapat dipahami sebagai sebuah usaha atau pemikiran yang sistematik untuk menemukan, mengembangkan dan menguji kebenaran fakta-fakta yang didasarkan pada ilmu pengetahuan (dengan metode ilmiah). Sehingga bisa disimpulkan, filosofi dari sebuah penelitian adalah penyaluran rasa ingin tahu manusia dengan perlakuan cermat dan teliti sehingga diperoleh jawaban. Baca; Lili Surayya Eka Putri, Metodologi penelitian untuk bidang Sains, Jakarta: UIN Jakarta Press, 2007,h. 01.

3 Dalam kamus Umum Bahasa Indonesia, W.J.S. Poerwadarminta mengartikan konstruksi sebagai sebuah cara untuk membuat (menyusun) bangunan-bangunan (jembatan dan sebagainya); dan dapat pula berarti susunan dan hubungan kata di kalimat atau di kelompok kata. W.J.S sangat mutlak diperlukan, konstruksi itu sendiri dapat ditinjau baik dari sisi konstruk berpikir si peneliti dalam sebuah penelitian maupun dari sisi konstruk bahasa yang digunakan, sehingga poinpoin yang hendak dicari maupun disampaikan dalam sebuah penelitian dapat menjadi lebih mudah dipahami baik untuk para pembaca hasil penelitian tersebut maupun demi kepentingan sang peneliti itu sendiri. Karena apabila yang terjadi adalah justru sebaliknya, maka problematika yang muncul kemudian adalah kegiatan penelitian tersebut akan menemui kesulitan-kesulitan dalam menemukan poin jawaban yang hendak ditemukan dalam penelitian itu sendiri apalagi alih-alih bagi kepentingan dan kemudahan setiap pembaca hasil penelitian tersebut. Di sini harus lah selalu disadari sepenuhnya kembali bahwa setiap para sarjana baik itu pada tingkatan sarjana, master, apalagi tingkat doktoral mutlak harus mengetahui bahwa syarat sebuah penelitian ilmiah yang baik haruslah tersusun secara sistematis dan terkontrol, serta harus kritis, lebih-lebih di dalam upaya penganalisisannya yang tentu saja harus memuat data-data yang terkonstruk secara berhubungan atau setidaknya memiliki hubungan yang kuat satu sama lain. ${ }^{4}$

Adapun kaitannya dengan apa yang kemudian ditulis oleh Muljono Damopolii dalam penelitian disertasinya, secara khusus pada bagian pendahuluan, di sini meskipun sebetulnya secara sekilas bisa reviewer pahami bahwa pada dasarnya peneliti tersebut telah berusaha secara apik

Poerwadarminta, Kamus Umum Bahasa Indonesia, Jakarta: Balai Pustaka, 1991, cet. XII,h. 520.

4 Abudin nata, Metodologi Studi Islam, Jakarta: PT RajaGrafindo Persada,2004, h. 167. 
untuk dapat menguraikan problem mendasar dari penelitian disertasi yang hendak dia lakukan. Hanya saja, jika mau dinilai secara jujur, reviewer dapat katakan bahwa apa yang dituliskan oleh Muljono Damopolii dalam pendahuluan atau latar belakang penelitian tersebut masih muncul banyak ketimpangan baik ditinjau dari sisi penyusunan alur kalimat antar alinea maupun konstruk alur berpikir yang cenderung kurang runtut dalam menguraikan permasalahan yang hendak dikaji. Sehingga kesan dan kesulitan yang muncul kemudian adalah pembaca sulit untuk menemukan poin mendasar mengenai apa yang menjadi kegelisahan akademik Muljono Damopolii selaku peneliti. Padahal sesungguhnya Muljono Damopolii sendiri dapat menggunakan alur berpikir yang sederhana baik itu memilih alur berpikir deduktif maupun induktif untuk menjelaskan permasalahan penelitiannya tersebut. ${ }^{5}$ Kesederhanaan sebagai sikap ilmiah harus senantiasa dijunjung tinggi oleh setiap peneliti, sebagaimana ungkapan Albert Einstein "If you can't explain it simply, you don't understand it well enough." kesederhanaan sikap ilmiah disini berarti bahwa cara berpikir, cara menyatakan pendapat, atau cara pengujian dilakukan dengan cara sederhana. Ini berarti bahwa jika suatu gejala dapat diterangkan secara memadai oleh suatu penjelasan, maka

5 Alur Berfikir Deduktif adalah suatu metode berpikir yang menerapkan hal-hal yang umum terlebih dahulu untuk seterusnya dihubungkan dalam bagian-bagian yang khusus. Sedangkan Alur berpikir secara induktif adalah proses berpikir dari pernyataan yang bersifat khusus ke pernyataan yang bersifat umum. Lihat: Moch Ainin, Metodologi Penelitian Bahasa Arab, Surabaya: Hilal Pustaka, 2007, h. 5. Lihat juga: Anton Bakker dan Achmad Charris Zubair, Metodologi Penelitian Filsafat, Yogyakarta: Kanisius,1990. h. 43 penjelasan lain yang lebih rumit tidak perlu dilakukan secara berliku-liku dan mengacaukan, tetapi dengan cara yang mudah dimengerti dan dipahami. ${ }^{6}$

Sampai sejauh ini reviewer sendiri pun masih sedikit menerka-nerka mengenai apa yang sesungguhnya menjadi kegelisahan akademik Muljono Damopolii sehingga membuatnya merasa perlu untuk mewacanakan penelitian pembaruan di lembaga pendidikan Islam di Makassar. Bahkan, apa yang menjadi keunikan dari Pesantren Modern Pendidikan Al Quran IMMIM itu pun juga sebetulnya belum begitu detail diungkapkan oleh Muljono damopolii, padahal pembahasan tersebut tentu saja sangat penting untuk dapat menjadi alasan dasar akan ketertarikannya untuk meneliti di tempat yang memang dia kehendaki.

Adapun kaitannya dengan hal tersebut, reviewer dapat menjelaskan bahwa dalam beberapa bagian alinea pendahuluan khususnya di alinea pertama dan kedua dari disertasi Muljono Damopolii tidaklah secara langsung mengutarakan problematika dari penelitiannya bahkan malah secara tibatiba langsung masuk ke ranah lembaga yang hendak dia teliti. Kemudian dilanjutkan dengan langsung mengeksplorasi secara lebih mendalam mengenai seluk beluk sejarah dan konsep pengorganisasian lembaga tersebut. ${ }^{7}$ Pada

6 Irawan Soehartono, Metode Penelitian Sosial: Suatu teknik penelitian bidang kesejahteraan sosial dan ilmu sosial lainnya, Bandung: PT Remaja Rosdakarya,2008, h.8

7 Berikut Reviewer kutip tulisan Muljono Damopolii pada alinea pertama dan kedua: "Wacana pembaruan pendidikan Islam di Makassar mendapat momentumnya sekitar pertengahan tahun 1970-an. Realisasinya adalah didirikannya sebuah lembaga pendidikan untuk umat Islam yang diberi nama "Pesantren Modern Pendidikan Al-Qur'an 
wilayah inilah sebenarnya yang menurut reviewer masih menjadi salah satu kelemahan dari disertasi Muljono Damopolii. Oleh sebab itulah, seharusnya hal ini dapat dipahami secara baik oleh setiap peneliti bahwa bagi setiap penelitian apapun yang hendak dilakukan idealnya haruslah di mulai dengan memunculkan secara jelas masalah atau sesuatu yang menjadi kegelisahan akademik dari si peneliti itu sendiri yang kemudian dapat menjadi pijakan dasar untuk melakukan penelitiannya secara lebih lanjut, atau dalam beberapa istilah yang sering dikutip dalam beberapa buku penelitian bahwa apa yang harus dimunculkan dalam bab pendahuluan atau latar belakang masalah dari sebuah rancangan penelitian adalah wajib akan adanya garis perbedaan yang jelas antara wilayah Das Sein (keadaan yang sebenarnya pada waktu sekarang) dan Das Sollen (berarti apa yang dicitacitakan; apa yang harus ada).

Selanjutnya, selain kritik tersebut diatas, kritik lain yang dapat reviewer ajukan terhadap disertasi Muljono

IMMIM Makassar". Pendirian lembaga pendidikan ini menjadi menarik untuk dikaji mengingat kehadirannya merupakan hasil sinergi dari berbagai kelompok masyarakat muslim di Makassar, baik yang berlatar belakang NU, Muhammadiyah, maupun yang lainnya. Pembaruan pendidikan Islam di Makassar mengambil bentuk lembaga pesantren sebagai wadah gerakannya. Akan tetapi, lembaga pesantren di sini tidak lagi mempertahankan karakteristik ketradisionalannya semata, melainkan telah mentransformasikan dirinya sesuai tuntutan kebutuhan masyarakat dan kondisi daerah yang bersangkutan. Sebab, para pendirinya menyadari betul bahwa mendirikan lembaga pendidikan, seperti lembaga pesantren, yang terlalu mempertahankan sifat ketradisionalannya, akan sulit untuk tetap survive." Lihat Muljono Damopolii, Pembaruan Pendidikan Islam di Makassar; Studi kasus pesantren Modern Pendidikan al Qur'an IMMIM Tamalanrea Makassar, Disertasi, Jakarta: UIN Syarif Hidayatullah, 2006, h. 1
Damopolii adalah mengenai adanya inkonsistensi dari penjelasan Muljono ketika mengungkapkan salah satu alasan yang mendasari penelitiannya mengenai Pembaruan Pendidikan Islam di Makassar berupa Studi kasus pesantren Modern Pendidikan al Qur'an IMMIM Tamalanrea. Dalam tulisannya diungkapkan bahwa salah satu alasan yang mendasari penelitiannya adalah dikarenakan masih sangat minimnya penelitian yang mengkaji pada bidang yang dia geluti yakni pendidikan. Berikut reviewer kutip apa yang Muljono Damopolii tuliskan dalam bagian latar belakang masalah dari disertasinya:

"Dari sekian banyak peran dan kontribusi yang melekat pada organisasi IMMIM, sepanjang penelusuran penulis, baru bidang dakwahlah yang pernah mendapat perhatian serius untuk diteliti dan dituangkan dalam sebuah karya skripsi yang ditulis oleh Muchlis Usman. Penelitian tersebut diberi judul "Peranan IMMIM dalam Pembinaan Da'wah Islam Menuju Integrasi Ummat di Sulawesi Selatan". Sedangkan bidang lainnya, termasuk bidang pendidikan, belum mendapatkan perhatian yang signifikan untuk diteliti dan dikaji secara ilmiah. Padahal dalam struktur kepengurusan DPP IMMIM dengan jelas tercantum salah satu majelis yang diberi nama Majelis Pendidikan dan Kebudayaan."

Padahal jika kemudian ditelusuri lebih lanjut pada bagian penelitian terdahulu (prior research) maka akan

8 Lihat Muljono Damopolii, Pembaruan Pendidikan Islam di Makassar; Studi kasus pesantren Modern Pendidikan al Qur'an IMMIM Tamalanrea Makassar, Disertasi, Jakarta: UIN Syarif Hidayatullah, 2006, h. 4 
diketemukan cukup banyak sekali penelitian yang mengkaji pesantren Modern Pendidikan al Qur'an IMMIM Tamalanrea Makassar sebagai objek kajiannya, bahkan dalam bidang yang sama dengan Muljono Damopolii yaitu bidang pendidikan. Diantara penelitianpenelitian tersebut seperti: Pertama, Penelitian M. Radhi Al-Hafid dengan judul "Sistem Pengajaran Bahasa Arab di Pesantren Modern Pendidikan Al-Qur'an IMMIM Ujungpandang Sulawesi Selatan". Kedua, Penelitian Muhammad Naim, dengan judul "Pesantren Modern Pendidikan Al-Qur'an IMMIM Tamalanrea Kecamatan Biringkanaya Ujungpandang 1975-1995 (Suatu Tinjauan Sejarah)". Ketiga, Penelitian Ahsan Mahmud dengan judul "Perspektif Pesantren Modern IMMIM Putra dalam Upaya Peningkatan Mutu Pendidikan Islam". Keempat, Penelitian Husniati Ahmad berjudul "Prospek Pembinaan Pesantren Modern IMMIM sebagai Wadah Pengembangan Sumber Daya Manusia yang Berkualitas di Ujungpandang". Kelima, Penelitian Arif Rahman Hakim yang menulis skripsi dengan judul "Studi tentang Kemampuan Penggunaan Isim dalam Jumlah pada Siswa Madrasah Tsanawiyah (SMP) Pesantren Putra IMMIM Ujungpandang”. Studi tentang Pesantren Modern Pendidikan Al-Qur'an IMMIM Makassar. ${ }^{9}$

Satu hal lagi yang juga harus dipahami dalam setiap kegiatan penelitian ilmiah adalah setiap unsur-unsur penulisan dalam sebuah penelitian haruslah memiliki konsistensi bersama dalam satu struktur,

9 Lihat Muljono Damopolii, Pembaruan Pendidikan Islam di Makassar; Studi kasus pesantren Modern Pendidikan al Qur'an IMMIM Tamalanrea Makassar, Disertasi, Jakarta: UIN Syarif Hidayatullah, 2006, h. 16-19. tidak boleh ada ketidakselarasan atau kontradiksi antara masing-masing mereka. Pemahaman yang baik akan ditemukan bukanlah dari pemahaman yang parsial akan tetapi justru dari pemahaman yang menyeluruh itu unsur-unsur khusus akan mendapat artinya dan kedudukannya. Dari lain pihak struktur bersatu itu hanya dapat dicapai melalui pemahaman satu persatu mengenai unsur-unsur parsial itu. ${ }^{10}$

\section{Kritik Poin Penelitian Terdahulu (Prior Research on Topic)}

Ketika berbicara tentang penelitian terdahulu yang relevan atau yang dalam istilah dari M Amin Abdullah yakni Prior Research On Topic, dikatakan bahwa tidaklah semua buku yang dibaca harus masuk ke proposal atau naskah penelitian (skripsi, tesis, disertasi) tetapi hanya bukubuku dari hasil penelitian terdahulu yang terkait sajalah yang perlu dipertimbangkan dengan cermat. ${ }^{11}$ Hal ini sangat wajar jika kemudian harus disinggung, karena memang pada dasarnya tidak sedikit penelitian yang biasanya cenderung memasukkan banyak buku ke dalam kajian penelitiannya tanpa terlalu memperhitungkan apakah buku-buku yang dimasukkan tersebut cukup relevan atau tidak dengan tema penelitian yang hendak dia kaji. Oleh sebab itulah Amin Abdullah mengintrodusir perlunya setiap peneliti agar selalu mencermati, mencari dan membangun metode, epistemologi, dan kerangka teori, khususnya menyadari begitu pentingnya prior research untuk

${ }^{10}$ Anton Bakker dan Achmad Charris Zubair, Metodologi Penelitian Filsafat, Yogyakarta: Kanisius, 1990. h. 103

11 M. Amin Abdullah, et.al, Metodologi Penelitian Agama Pendekatan Multidisipliner, Yogyakarta: Lembaga Penelitian UIN Sunan Kalijaga, 2006,h. 215 
pengembangan keilmuan keislaman (contribution to knowledge) lebih-lebih kepada mahasiswa program magister dan doktor. $^{12}$ Kesadaran akan pentingnya penelitian terdahulu dalam setiap kegiatan penelitian, selain membantu sang peneliti untuk dapat menempatkan sumber-sumber yang digunakan dalam lingkup yang lebih relevan, juga akan membantu dan menginspirasi si peneliti untuk selalu giat mengembangkan temuan-temuan baru dalam penelitiannya, karena apa yang di kerjakan penelitiannya terhindari dari sesuatu yang bersifat repetisi (pengulangan) semata. Hal ini sebagaimana yang diingatkan oleh William Asher "If man is not aware of what has been learned in history, it is said he is bound to repeat the experiences." 13

Hal serupa juga muncul dalam tulisan disertasi Muljono Damopolii, meskipun memang tidak banyak, akan tetapi masih ada penelitian yang sebetulnya menurut reviewer kurang perlu untuk dimasukkan ke dalam kajian penelitiannya yang terdahulu, diantaranya yaitu: Skripsi Arif Rahman Hakim dengan judul "Studi tentang kemampuan penggunaan Isim dalam Jumlah pada siswa Madrasah Tsanawiyah (SMP) Pesantren Putra IMMIM Ujung Pandang." Kajian penelitian ini kurang relevan dengan apa yang hendak ditulis oleh Muljono Damopolii dalam disertasinya karena tidak secara spesifik membahas tentang isu pembaruan pendidikan Islam.

12 M Amin Abdullah, Islamic Studies Di Perguruan Tinggi; Pendekatan IntegratifInterkonektif, Yogyakarta : Pustaka pelajar2006, h. 199.

${ }^{13}$ William Asher J, Educational Research and Evaluation Methode, Litthle,Brown and company, Boston, Toronto, 1976.h. 216.

\section{E. KRITIK POIN METODOLOGIS}

Penelitian dipandang sebagai kegiatan ilmiah karena menggunakan metode keilmuan, yakni gabungan antara pendekatan rasional dan pendekatan empiris. Pendekatan rasional adalah berfungsi untuk memberikan kerangka pemikiran yang koheren dan logis. Sedangkan pendekatan empiris merupakan kerangka pengujian dalam memastikan kebenaran. Jadi penelitian ilmiah adalah suatu kegiatan yang dilakukan dengan mengikuti prinsip kerja ilmu pengetahuan. Penelitian ilmiah dilaksanakan berdasarkan atas masalah dan masalah yang diteliti tidak boleh berdasarkan dugaan tetapi benar-benar ada datanya dan dapat ditemukan dilapangan. ${ }^{14}$ Dalam kegiatan penelitian ilmiah harus diingat bahwa aspek metodologi adalah masalah yang sangat penting khususnya dalam sejarah pencapaian pertumbuhan ilmu. Sehingga persoalan ini tidaklah dapat dikesampingkan begitu saja oleh setiap peneliti manapun, memilih metode kognitif yang betul untuk mencari kebenaran adalah lebih penting dari pada filsafat, sains atau hanya sekedar mempunyai bakat. ${ }^{15}$

Lalu, pertanyaan yang muncul kemudian yaitu apakah metode yang paling baik digunakan dalam setiap kegiatan penelitian? Untuk menjawab pertanyaan tersebut, perlu digarisbawahi bahwa sesungguhnya dewasa ini metodemetode ilmiah dalam segala cabang ilmu pengetahuan telah mengalami perubahan yang cukup massif bahkan pendekatanpendekatan baru juga telah banyak

14 Yatimin Abdullah, Studi Islam Kontemporer, Jakarta: Amzah,2006. h.216

15 Mukti Ali, Metode Memahami Agama Islam, Jakarta: Bulan Bintang,1991.h. 27 
ditemukan. Oleh sebab itu jelas, bahwa menetapkan satu metode saja tidak bisa dipilih untuk mempelajari sesuatu objek penelitian. ${ }^{16}$ Selain itu persoalan untuk bagaimana memilih suatu metode yang tepat sasaran, maka penggunaan metode dalam setiap kegiatan penelitian harus disesuaikan dengan objek penelitian itu sendiri. Hal ini sebagaimana yang ditegaskan oleh Mukti Ali bahwa Obyek studi itu sendirilah yang menentukan metode, dan bukan sebaliknya. ${ }^{17}$

Terkait dengan apa yang ditulis oleh Muljono Damopolii dalam penelitian disertasinya, ada beberapa hal yang cukup mengganggu pikiran reviewer khususnya berkenaan dengan aspek metodologi yang Muljono Damopolii gunakan, diantaranya yaitu:

Pertama, Muljono Damopolii mengatakan bahwa dalam penelitiannya dia menggunakan dua metode penelitian, yaitu metode penelitian kualitatif dan metode penelitian kuantitatif, berikut reviewer kutip pernyataannya dalam bagian metodologi: “...Jenis penelitian ini dapat digolongkan sebagai penelitian kualitatif, tetapi tetap mengakomodasi dimensi kuantitatif. hal ini logis karena penelitian ini merupakan studi kasus terhadap pembaruan pendidikan yang dilakukan oleh Pesantren IMMIM Makassar. Artinya, dalam penelitian ini terdapat sejumlah data yang harus dikuantifikasi dengan jalan mengolahnya ke dalam tabel frekuensi kemudian dicari distribusi persentasenya." 18

\footnotetext{
${ }^{16}$ Taufiq Abdullah, ed, Metodologi Penelitian Agama; Suatu Pengantar, Yogyakarta: Tiara Wacana, 2004.h.56.

17 A Mukti Ali, et al, Metode Memahami Agama Islam, Jakarta: Bulan Bintang,1991.h.9

18 Lihat Muljono Damopolii, Pembaruan Pendidikan Islam di Makassar; Studi kasus
}

Namun demikian, dalam wilayah pembahasannya kenyataan yang terjadi justru sangatlah jauh berbeda, Muljono sama sekali tidak menggunakan metode campuran (Mixing method), penelitian yang dia gunakan hanyalah penelitian kualitatif an sich, tanpa mengakomodasi sama sekali dimensi kuantitatif. ${ }^{19} \mathrm{Hal}$ inilah sebagaimana yang reviewer paparkan dalam pembahasan sebelumnya bahwa ada beberapa pembahasan Muljono Damopolii yang cenderung tidak konsisten. Karena jika memang Muljono mau menggunakan metode penelitian kuantitatif tentu saja di dalamnya harus memuat pendekatan-pendekatan yang mencerminkan ciri-ciri penelitian kuantitatif, diantaranya yaitu mengarahkan pola pikir yang menunjukkan hubungan antar variable yang akan diteliti yang sekaligus mencerminkan jenis dan jumlah rumusan masalah yang perlu dijawab melalui penelitian, teori yang digunakan untuk merumuskan hipotesis, jenis dan jumlah hipotesis serta teknik analisis statistik yang digunakan. Adapun selain itu Muljono juga harus memilih modelmodel pengujian hipotesis yang akan dia gunakan, seperti pengujian hipotesis deskriptif, pengujian hipotesis komparatif, dan pengujian hipotesis hubungan (asosiatif). Termasuk pula memilih teknik analisis yang akan dia gunakan dalam

pesantren Modern Pendidikan al Qur'an IMMIM Tamalanrea Makassar, Disertasi, Jakarta: UIN Syarif Hidayatullah, 2006, h. 21

${ }^{19}$ Penilaian reviewer ini dapat dirujuk pada tulisan Muljono Damopolii khususnya pada bagian BAB V, Pesantren Modern Pendidikan Al-Qur'an IMMIM Makassar dan Pembaruannya. Lihat Muljono Damopolii, Pembaruan Pendidikan Islam di Makassar; Studi kasus pesantren Modern Pendidikan al Qur'an IMMIM Tamalanrea Makassar, Disertasi, Jakarta: UIN Syarif Hidayatullah, 2006, h.186-333. 
penelitiannya seperti teknik analisis regresi maupun teknik analisis jalur. ${ }^{20}$

Kedua, berkenaan dengan pendekatan-pendekatan yang digunakan Muljono Damopolii dalam penelitiannya. Muljono memaparkan bahwa dia menggunakan pendekatan grounded research atau grounded theory dalam penelitiannya, sebagaimana yang dapat reviewer kutip berikut ini: “...Selanjutnya, penelitian yang bersifat kualitatif ini tidak dapat dipisahkan dari pendekatan grounded research ${ }^{21}$ atau grounded theory ${ }^{22}$ yang intinya adalah semua analisis harus berdasarkan data yang ada dan bukan berdasarkan berbagai ide yang ditetapkan sebelumnya. Oleh karena itu, teori yang grounded adalah teori yang diperoleh secara induktif dari penelitian tentang fenomena yang dijelaskannya. Peneliti tidak memulai penelitiannya dengan satu teori tertentu lalu membuktikannya, tetapi memulai dengan suatu bidang kajian dan hal-hal yang terkait dengan bidang tersebut." 23

Sebagaimana yang dijelaskan oleh Muljono Damopolii sendiri bahwa pendekatan grounded research atau grounded theory selalu menghindari berbagai ide maupun teori yang telah ditetapkan sebelumnya, dimana si peneliti harus memulai penelitiannya tanpa

20 Sugiono, Statistika untuk penelitian, Bandung: Alfabeta, 2009,h.8

21 Mastuhu, Dinamika Sistem Pendidikan Pesantren: Studi Kajian tentang Unsur dan Nilai Sistem Pendidikan Pesantren, h. 46.

22 Anselm Strauss dan Juliet Corbin, Dasardasar Penelitian Kualitatif: Tatalangkah dan Teknik-teknik Teoritisasi Data, Yogyakarta: Pustaka Pelajar, 2003, h. 10.

23 Lihat Muljono Damopolii, Pembaruan Pendidikan Islam di Makassar; Studi kasus pesantren Modern Pendidikan al Qur'an IMMIM Tamalanrea Makassar, Disertasi, Jakarta: UIN Syarif Hidayatullah, 2006, h.21. berpijak sama sekali pada acuan teori tertentu dalam pembuktiannya. Hanya saja, jika ditelusuri secara lebih mendalam terhadap penelitian Muljono Damopolii baik setuju maupun tidak, kenyataannya dia telah menggunakan suatu model teori pembaruan pendidikan, yang dalam hal ini dia menggunakan acuan model teori pembaruan pendidikan pesantren Azyumardi Azra. Secara lebih detil berikut penulis kutipkan apa yang ada dalam disertasi Muljono Damopolii tersebut dalam beberapa halaman yang berbeda: “...Serangkaian model pembaruan pesantren seperti yang diungkapkan Azra di atas dapat diberlakukan bagi keseluruhan komponen pendidikan pesantren. Perlu ditekankan di sini bahwa penggunaan istilah komponen pendidikan pesantren dalam tulisan ini merujuk kepada tujuan, kelembagaan, keorganisasian, kurikulum, dan tenaga pengajar. Artinya, yang menjadi obyek pembaruan pada sistem pendidikan pesantren adalah keseluruhan komponen pendidikan pesantren tersebut." 24 “...Dalam penelitian ini, obyek pembaruan yang meliputi komponen tujuan, kelembagaan, keorganisasian, kurikulum, metodologi, dan tenaga pengajar diasumsikan bukan saja terdapat pada pesantren dengan ciri modern, tetapi juga pada pesantren dengan ciri tradisional. Itulah sebabnya, pembaruan pesantren baik yang masih berciri tradisional maupun yang sudah berciri modern selalu menitikberatkan pembahasannya pada komponen-komponen di atas untuk

24 Lihat Muljono Damopolii, Pembaruan Pendidikan Islam di Makassar; Studi kasus pesantren Modern Pendidikan al Qur'an IMMIM Tamalanrea Makassar, Disertasi, Jakarta: UIN Syarif Hidayatullah, 2006, h.43-44. 
menentukan sejauhmana pembaruan telah terjadi." 25

Dari pernyataan Muljono Damopolii tersebut bisa disimpulkan bahwa apa yang dilukiskannya mengenai pendekatan grounded research atau grounded theory yang akan digunakannya dalam penelitian, secara langsung maupun tidak langsung ternyata dimentahkan sendiri dalam pembahasannya yang lebih lanjut. Karena memang pada akhirnya dia sendiri ternyata juga menggunakan acuan sebuah teori yang telah dia tetapkan sebelumnya yaitu teori pembaruan pendidikan pesantren Azyumardi Azra.

Selanjutnya reviewer coba telusuri secara lebih jauh dengan mempertanyakan kembali berbagai aspek lain yang tercakup di dalamnya, jika memang benar bahwa Muljono Damopolii menggunakan pendekatan grounded theory dengan melepaskan sama sekali asumsi dan teoriteori ilmiah sebelum melakukan kegiatan penelitian, lantas darimanakah Muljono Damopolii memperoleh istilah-istilah yang digunakannya sebagai sebuah hasil dari temuan-temuan penelitiannya? Untuk menjawab pertanyaan tersebut, Sebelumnya reviewer kutipkan beberapa temuan-temuan ilmiah yang Muljono Damopolii paparkan dari hasil penelitiannya di Pesantren Modern Pendidikan Al-Qur'an IMMIM Tamalanrea Makassar, yaitu: (1) ditinjau dari sisi komponen tujuan pendidikan, maka pembaruan lembaga pendidikan Islam di Makassar bercorak dinamis; (2) ditinjau dari komponen kelembagaan dan keorganisasian maka pembaruan pendidikan Islamnya bercorak Transformatif; (3) ditinjau dari komponen

${ }^{25}$ Ibid, h. 95 kurikulum cenderung bercorak fleksibel; (4) ditinjau dari komponen metodologi pembelajaran cenderung bercorak eklektifinovatif; (5) ditinjau dari sisi komponen tenaga pengajar cenderung bercorak professional. $^{26}$

Secara jujur, reviewer sesungguhnya merasa ragu dengan hasil temuan-temuan penelitiannya tersebut. Kalaupun memang dia menggunakan pendekatan grounded theory dalam penelitiannya, seharusnya temuan-temuan penelitian yang dia paparkan harus merupakan konstruksi yang dibuat sendiri oleh obyek maupun subyek penelitiannya yang dalam hal ini adalah konstruksi sendiri dari Pesantren Modern Pendidikan Al-Qur'an IMMIM Tamalanrea Makassar, dan bukan malah sebaliknya, dimana hasil penelitiannya justru merupakan hasil pemetaan dan konstruksi dari si peneliti itu sendiri. Dalam hal ini reviewer agaknya cukup sangsi dengan beberapa istilah dari pemetaan corak-corak pembaruan pendidikan Islam yang ditemukan Muljono Damopolii tersebut seperti: dinamis, transformatif, fleksibel, eklektifinovatif, dan professional adalah merupakan hasil konstruksi dari pihak lembaga tempat penelitian itu sendiri. Reviewer justru melihat bahwa temuantemuan tersebut lebih merupakan sebuah konstruksi pribadi dari pihak Muljono Damopolii.

Sebagai sebuah perbandingan, reviewer akan coba sandingkan penelitiannya Muljono Damopolii dengan hasil penelitian disertasi Clifford Geertz ketika meninjau masyarakat jawa. Dalam

26 Lihat Muljono Damopolii, Pembaruan Pendidikan Islam di Makassar; Studi kasus pesantren Modern Pendidikan al Qur'an IMMIM Tamalanrea Makassar, Disertasi, Jakarta: UIN Syarif Hidayatullah, 2006, h. 334. 
penelitiannya, Clifford Geertz pada akhirnya berhasil memperoleh temuantemuan penelitian berupa tiga varian kelompok dalam masyarakat jawa, yakni abangan, santri, dan priyayi. Satu hal yang menarik dari penelitian tersebut, dengan mencoba beranjak dari pendekatan grounded theory, Geertz berhasil menghasilkan temuan-temuan penelitian yang memang merupakan hasil konstruksi dari masyarakat jawa itu sendiri, bukan pemetaan yang dia buat-buat sendiri. Berikut reviewer kutipkan hasil tulisan Clifford Geertz sebagai bahan perbandingan: “...Penduduk Mojokuto dibagi dalam kelompok-kelompok menurut pandangan hidup mereka 'menurut kepercayaan agama, preferensi etis dan ideology politik mereka - maka terdapatlah tiga tipe budaya utama. Ketiga tipe itu dinamakan berturut-turut abangan, santri, dan priyayi. Abangan, yang menekankan aspek-aspek animisme sinkretisme Jawa secara keseluruhan dan pada umumnya diasosiasikan dengan unsure petani desa penduduk santri, yang menekankan aspek-aspek Islam sinkretisme itu dan pada umumnya diasosiasikan dengan unsure pedagang (dan juga dengan unsur-unsur tertentu kaum tani); dan priyayi, yang menekankan aspek-aspek Hindu dan diasosiasikan dengan unsur birokrasi..." “...Pembagian dalam tiga bagian ini, menurut Geertz merupakan pembagian yang dibuat oleh orang-orang Jawa sendiri." 27

Ketiga, berkaitan dengan pendekatan historis atau sejarah yang digunakan oleh Muljono Damopolii. Berikut reviewer kutip pernyataan Muljono dalam

27 Clifford Geertz, Abangan, Santri, Priyayi Dalam Masyarakat Jawa, Jakarta: Pustaka Jaya, 1983.h. 524 disertasinya: "...Penelitian ini menggunakan pula pendekatan historis dengan asumsi bahwa kajian pembaruan pendidikan Islam yang menempatkan Pesantren Modern Pendidikan Al-Quran IMMIM Makassar sebagai wadah berlangsungnya proses pembaruan itu terikat dengan dimensi sejarah. Artinya, dengan pendekatan historis, penelitian ini mencoba mengupayakan agar pemikiran, gagasan, dan konsep pembaruan pendidikan Islam tersebut benar-benar dapat dibuktikan adanya melalui data-data yang dapat dilacak dalam dokumen sejarah atau secara empirik dapat dilakukan konfirmasi silang terhadap keakuratan data yang diperoleh melalui wawancara kepada para informan. Hal ini dimungkinkan karena melalui pendekatan historis diasumsikan bahwa segala peristiwa dapat dilacak dengan melihat kapan peristiwa itu terjadi, di mana, apa sebabnya, dan siapa yang terlibat dalam peristiwa tersebut. Jadi, melalui pendekatan ini seseorang diajak menukik dari alam idealis ke alam yang bersifat empiris dan mendunia."

Persoalannya kemudian adalah Muljono Damopolii tidaklah menjelaskan secara lebih detail mengenai bagaimana pendekatan sejarah itu dilakukan, atau bisa dikatakan dia tidak menggunakan satu kerangka konsep utuh mengenai bagaimana pendekatan sejarah itu sendiri akan digunakan. Perlu disadari secara lebih jauh bahwa pendekatan sejarah seharusnya tidaklah hanya digunakan untuk meninjau peristiwa-peristiwa masa lalu yang kemudian dilacak baik melalui dokumen-dokumen sejarah maupun konfirmasi silang terhadap data melalui wawancara dengan para pelaku sejarah. Akan tetapi secara lebih jauh pendekatan sejarah harus mampu keluar dari yang 
hanya sekedar mendeskripsikan kejadian masa lalu menuju pada upaya menjelaskan perubahan-perubahan yang terjadi dengan sejarah serta perkembangan kontemporer dari sejarah itu sendiri. Sehingga dari sinilah bisa ditemukan pertautan antara penjelasan fakta sejarah di masa lalu dengan kondisi riil kekinian.

Atas dasar itulah pendekatan sejarah yang dilakukan oleh Muljono Damopolii dalam disertasinya sesungguhnya akan jauh lebih memadai jika dia mau menggunakan kerangka konsep dari pendekatan sejarah yang ditawarkan oleh M Amin Abdullah yang meliputi: Origin, Change, and Development. Ketiga kerangka berpikir dalam pendekatan sejarah ini dapat dijabarkan sebagai berikut: Origin (asal usul), dalam pengertian ini pendekatan sejarah harus mampu mengungkap mengenai bagaimana asal-usul dari subyek penelitian yang hendak atau sedang dikaji. Change (perubahan dan perkembangan), dalam pengertian ini pendekatan sejarah harus mampu mengungkap mengenai bagaimana perubahan dan perkembangan subyek penelitian dalam lintasan sejarah, Development (perkembangan dalam konteks kekinian), dalam pengertian ini pendekatan sejarah harus dapat mengungkapkan mengenai bagaimana persinggungan sebuah subjek penelitian dengan konteks kekinian, apakah subyek dapat mengakomodasi lingkup sekelilingnya atau justru sebaliknya.

\section{F. TAWARAN TEORI}

Sehubungan dengan poin kritik ketiga yang reviewer soroti pada bagian pendekatan teori sejarah yang digunakan oleh Muljono Damopolii dalam penelitiannya. Reviewer memandang bahwa pendekatan sejarah yang digunakan oleh Muljono Damopolii belum memiliki satu kerangka komprehensif yang dapat menjelaskan mengenai bagaimana pendekatan itu akan dilakukan. Sehingga dari situ akan nampak satu kebingungan peneliti itu sendiri mengenai akan dibawa kearah manakah penelitiannya tersebut.

Beranjak dari permasalahan itulah reviewer mencoba menawarkan perspektif sejarah yang pernah dikemukakan oleh Amin Abdullah meliputi pemetaan: Origin, Change, and Development, Origin (asal usul), dalam pengertian ini pendekatan sejarah harus mampu mengungkap mengenai bagaimana asalusul dari subyek penelitian yang hendak atau sedang dikaji. Change (perubahan dan perkembangan), dalam pengertian ini pendekatan sejarah harus mampu mengungkap mengenai bagaimana perubahan dan perkembangan subyek penelitian dalam lintasan sejarah, Development (perkembangan dalam konteks kekinian), dalam pengertian ini pendekatan sejarah harus dapat mengungkapkan mengenai bagaimana persinggungan sebuah subjek penelitian dengan konteks kekinian, apakah subyek dapat mengakomodasi lingkup sekelilingnya atau justru sebaliknya. 


\section{G. PERSPEKTIF HISTORIS ${ }^{28}$}

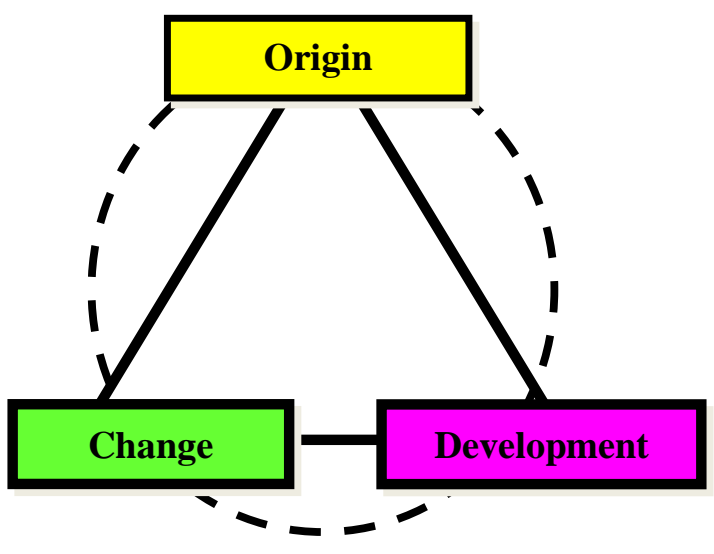

Adapun kaitannya dengan Disertasi Muljono Damopolii dapat reviewer jelaskan sebagaimana berikut: Pertama, pada wilayah Origin (asal usul) ini haruslah dapat mengungkapkan mengenai bagaimana asal usul kemunculan pesantren Modern Pendidikan al Qur'an IMMIM Tamalanrea Makassar, siapa pelaku-pelaku yang terlibat di dalamnya, bagaimana keadaan awal ketika lembaga tersebut berdiri, bagaimana keadaan sosial masyarakat sekitar lembaga tersebut pada waktu itu, dan lain sebagainya. Kedua, pada wilayah Change (perubahan dan perkembangan), pada wilayah ini peneliti haruslah dapat menguraikan bagaimana perkembangan lembaga pesantren Modern Pendidikan al Qur'an IMMIM Tamalanrea Makassar dalam lintasan sejarah, artinya peneliti harus dapat mengungkapkan bagaimana fase-fase perkembangan lembaga tersebut dari masa ke masa baik meliputi: Perubahan kepemimpinan dan tipologinya dari masa ke masa,

${ }^{28}$ M Amin Abdullah, Interconnected Link Keilmuan Hubungan Antara Syariah, Fikih Dan Faqih, Makalah tidak diterbitkan, makalah ini di sampaikan pada Lokakarya Peradilan Agama dan PSW UIN Sunan Kalijaga, di Bandung, 30 Desember 2010 perkembangan lembaga itu sendiri dari masa ke masa, dan tantangan-tantangan yang dihadapi dari masa ke masa. Ketiga, Development (perkembangan dalam konteks kekinian), pada fase ini lembaga pesantren Modern Pendidikan al Qur'an IMMIM Tamalanrea Makassar dilihat dan dipertemukan dengan konteks perkembangan arus kekinian, apakah lembaga tersebut mampu mengakomodasi realitas kekinian, atau justru malah yang terjadi sebaliknya.

Menurut hemat reviewer, seandainya Muljono Damopolii mau untuk melengkapi pendekatan sejarahnya melalui kerangka konsep yang reviewer tawarkan tersebut. Maka hasil penelitiannya akan jauh lebih rigid dan komprehensif, karena dalam hal ini secara langsung maupun tidak peneliti diarahkan untuk melakukan suatu periodisasi sejarah dari lembaga yang dia teliti tersebut. Selain itu dengan menggunakan kerangka pendekatan ini, si peneliti sesungguhnya akan dapat lebih mudah untuk melihat bagaimana pembaruan-pembaruan lembaga tersebut dilakukan.

\section{H. KESIMPULAN}

Penelitian disertasi merupakan puncak tertinggi dari penelitian yang dilakukan oleh para sarjana. Atas dasar itulah setiap hasil penelitian disertasi diharapkan dapat memberikan kontribusi yang signifikan dalam setiap bidang studi masing-masing, sehingga setiap ranah keilmuan akan senantiasa berkembang dari masa ke masa. Adapun penelitian disertasi yang dilakukan Muljono Damopolii di pesantren Modern Pendidikan al Qur'an IMMIM Tamalanrea Makassar merupakan satu penelitian disertasi yang dilakukan 
dengan penuh kesungguhan dan etos kerja yang tinggi.

Namun demikian, dengan tidak mengurangi rasa apresiasi terhadap hasil penelitian beliau, kajian kritis pembacaan yang reviewer lakukan ini bertitik tolak dari ungkapan pepatah, tiada gading yang tak retak. Dalam beberapa hal disertasi Muljono Damopolii tersebut ternyata masih memiliki beberapa kekurangan, diantaranya: Pertama, masih ada beberapa inkonsistensi-inkonsistensi yang terjadi di dalamnya; Kedua, ketidaktepatan penggunaan pendekatan-pendekatan dalam penelitiannya, seperti grounded theory; Ketiga, pendekatan historis yang digunakan harus dilengkapi dengan satu kerangka konsep yang utuh sehingga dapat menjelaskan kondisi dan perkembangan dari lembaga yang diteliti tersebut secara lebih komprehensif. Terakhir, kajian critical review ini tetap mengapresiasi dengan baik terhadap karya disertasi Muljono Damopolii sebagai karya yang baik dan serius dikerjakan. Wallahu A'lam bi Ash Shawwab.

\section{DAFTAR PUSTAKA}

Abudin Nata, Metodologi Studi Islam, cet. III, Jakarta: PT RajaGrafindo Persada, 1999. , Tokoh-tokoh Pembaruan Pendidikan Islam di Indonesia, Jakarta: PT Raja Grafindo Persada, 2005.

Anselm Strauss dan Juliet Corbin, Dasardasar Penelitian Kualitatif: Tatalangkah dan Teknik-teknik Teoritisasi Data, Yogyakarta: Pustaka Pelajar, 2003.

Anton Bakker dan Achmad Charris Zubair, Metodologi Penelitian Filsafat, Yogyakarta: Kanisius,1990.
Azyumardi Azra, Pendidikan Islam: Tradisi dan Modernisasi Menuju Milenium Baru, Jakarta: PT Logos Wacana Ilmu, 1999.

Clifford Geertz, Abangan, Santri, Priyayi Dalam Masyarakat Jawa, Jakarta: Pustaka Jaya, 1983.

Irawan Soehartono, Metode Penelitian Sosial: Suatu teknik penelitian bidang kesejahteraan sosial dan ilmu sosial lainnya, Bandung: PT Remaja Rosdakarya,2008.

Jusuf Amir Feisal, Reorientasi Pendidikan Islam, Jakarta: Gema Insani Press, 1995.

Lili Surayya Eka Putri, Metodologi penelitian untuk bidang Sains, Jakarta: UIN Jakarta Press, 2007.

M Amin Abdullah, et.al, Metodologi Penelitian Agama Pendekatan Multidisipliner, Yogyakarta: Lembaga Penelitian UIN Sunan Kalijaga, 2006.

M Amin Abdullah, Interconnected Link Keilmuan Hubungan Antara Syariah, Fikih Dan Faqih, Makalah tidak diterbitkan, makalah ini di sampaikan pada Lokakarya Peradilan Agama dan PSW UIN Sunan Kalijaga, di Bandung, 30

Desember 2010

-------------------, Islamic Studies Di

Perguruan Tinggi; Pendekatan Integratif-Interkonektif,

Yogyakarta : Pustaka pelajar2006.

Mastuhu, Dinamika Sistem Pendidikan

Pesantren: Studi Kajian tentang Unsur dan Nilai Sistem Pendidikan Pesantren, Jakarta : INIS,1994.

Mukti Ali, Metode Memahami Agama Islam, Jakarta: Bulan Bintang, 1991.

Muljono Damopolii, Pembaruan Pendidikan Islam di Makassar; Studi 
kasus pesantren Modern Pendidikan

al Qur'an IMMIM Tamalanrea

Makassar, Disertasi, Jakarta: UIN

Syarif Hidayatullah, 2006.

Nurcholish Madjid, "Pengantar", dalam A.

Malik Fadjar, Reorientasi

Pendidikan Islam, Jakarta: Fajar Dunia,1999.

Sugiono, Statistika untuk penelitian,

Bandung: Alfabeta, 2009.

Taufiq Abdullah, ed, Metodologi

Penelitian Agama; Suatu Pengantar, Yogyakarta: Tiara Wacana, 2004.

W.J.S. Poerwadarminta, Kamus Umum Bahasa Indonesia, Jakarta: Balai Pustaka, 1991, cet. XII.

William Asher J, Educational Research and Evaluation Methode, Litthle,Brown and company, Boston, Toronto, 1976.

Yatimin Abdullah, Studi Islam Kontemporer, Jakarta: Amzah,2006. 